\title{
WACANA INTELEKTUAL KEAGAMAAN ISLAM DI INDONESIA DENGAN TIMUR TENGAH
}

\author{
Maulida; Bukhari \\ IAIN Takengon \\ SMAN 15 Takengon Binaan Nenggeri Antara \\ maulidaamin03@gmail.com; bukhari15tkn@gmail.com
}

\begin{abstract}
Abstrak
Sejarah Islam dimulai dari Timur Tengah di wilayah Arab. Haramayn adalah dua kota Makkah dan Madinah berada di Timur Tengah sebagai pusat intelektual dunia Muslim, dimana ulama, sufi, filosof, penyair, pengusaha dan sejarawan Muslim bertemu dan saling menukar informasi. Hubungan intelektual para ulama Timur Tengah dengan para pelajar di Indonesia dalam bentuk murid dan guru di komunitas Jawi, telah memberikan andil sangat besar bagi pengakuan luas dari masyarakat bahwa mayoritas ulama Nusantara yang belajar di Timur Tengah mempunyai wibawa atau reputasi keulamaan yang baik. Hubungan tersebut terjalin sejak awal masuknya Islam dibawa oleh para pedagang Muslim dari Arab. Sejak abad ke-17 hubungan ini umumnya bersifat keagamaan, keilmuan, dan politik antar beberapa kerajaan Muslim Nusantara. Hubungan intelektual para ulama terkait paham keagamaan, yaitu harmonisasi antara syariat dan tasawuf.
\end{abstract}

Kata Kunci: Intelektual, Islam Indonesia, Timur Tengah

\begin{abstract}
Abstrak
The history of Islam started from the Middle East in the Arab region. Haramayn is the two cities of Makkah and Medina in the Middle East as the intellectual center of the Muslim world, where Muslim scholars, Sufis, philosophers, poets, businessmen and historians meet and exchange information. The intellectual relationship between Middle Eastern scholars and students in Indonesia in the form of students and teachers in the Jawi community, has contributed greatly to the widespread recognition of the public that the majority of Nusantara scholars who study in the Middle East have a good authority or scholarly reputation. This relationship was established since the beginning of the entry of Islam by Muslim traders from Arabia. Since the 17th century, this relationship has generally been religious, scientific, and political between several Muslim kingdoms in the archipelago. The intellectual relationship of the scholars is related to religious understanding, namely the harmonization of sharia and Sufism.
\end{abstract}

Keywords: Intellectual, Indonesian Islam, Middle East 


\section{PENDAHULUAN}

Haramayn sebagai dua kota Makkah dan Madinah yang berada di Timur Tengah. Haramayn disebut pusat intelektual dunia Muslim, dimana ulama, sufi, filosof, penyair, pengusaha dan sejarawan Muslim bertemu dan saling menukar informasi. Inilah yang menyebabkan ulama dan penuntut ilmu baik itu yang mengajar maupun belajar disana pada umumnya mempunyai pandangan keagamaan lebih luas. Sejak abad ke-17 hubungan antara Islam di Nusantara dengan Timur Tengah umumnya bersifat keagamaan dan keilmuan, meski juga terdapat hubungan politik antar beberapa kerajaan muslim Nusantara, misalnya dengan Dinasti Utsmani. ${ }^{1}$ Hubungan antara kaum Muslim di Indonesia dan Timur Tengah telah terjalin sejak masa-masa awal Islam. Para pedagang Muslim dari Arab, Persia, dan Anak Benua India yang mendatangi Indonesia tidak hanya berdagang, tetapi juga menyebarkan Islam kepada penduduk setempat. Kemakmuran kerajaan-kerajaan Muslim di Indonesia, memberikan kesempatan kepada masyarakat Muslim Indonesia untuk melakukan perjalanan ke pusat-pusat keilmuan dan keagamaan di Timur Tengah.

Upaya Dinasti Utsmani mengamankan jalur perjalanan haji, membuat perjalanan haji dari Indonesia semakin baik. Sejak abad ke-14 dan ke-15, hubungan ekonomi, politik, sosial-keagamaan antara negara Muslim di Indonesia dan Timur Tengah semakin meningkat. Maka, semakin banyaklah penuntut ilmu dan jemaah haji dari Indonesia yang berkesempatan mendatangi pusat keilmuan Islam di Timur Tengah. Murid-murid di Haramayn, setelah menuntut ilmu di Timur Tengah, sebagian besar mereka kembali ke Indonesia menjadi seorang ulama. Di Indonesia mereka menjadi penyebar utama tradisi intelektual-keagamaan Islam dari pusatpusat keilmuan Islam di Timur Tengah ke Indonesia. Kecendrungan intelektualkeagamaan paling mencolok yang muncul dari jaringan ulama tersebut adalah harmonisasi antara syariat dan tasawuf.

\section{PENGERTIAN INTELEKTUAL}

Intelektual dalam Bahasa Indonesia sebagai kata sifat artinya cerdas, berakal, dan berpikiran jernih berdasarkan ilmu pengetahuan, sebagai kata benda berarti orang yang mempunyai kecerdasan tinggi; cendikiawan; bisa juga disebut totalitas pengertian atau kesadaran, terutama yang menyangkut pemikiran dan pemahaman. $^{2}$ Secara harfiah, kata intelektual berasal dari Bahasa Inggris yaitu intellectual (termasuk kata sifat). Menurut As. Hornby et.al, intelektual berarti:

${ }^{1}$ Azyumardi Azra, Jaringan Ulama Timur Tengah dan Kepulauan Nusantara Abad XVII dan XVIII: Akar Pembaruan Islam Indonesia, (Jakarta: Kencana Prenadamedia Group, 2013), h. $\mathrm{XXV}$.

${ }^{2}$ Kamus Besar Bahasa Indonesia, Edisi Kelima, Badan Pengembangan dan Pembinaan Bahasa Kementerian Pendidikan dan Kebudayaan, 2018, h. 649. 
having or showing good reasoning power, ${ }^{3}$ artinya memiliki atau menunjukkan kekuatan penalaran yang baik. Menurut John \& Hassan, intellectual sebagai kata sifat berarti intelektual, cerdik, cendikia. ${ }^{4}$ Sedangkan dalam Bahasa Arab, intelektual adalah 'akala orang yang berakal, orang yang mengetahui, berbudaya, akal, pikiran.

Menurut George A. Theodorson dan Achilles G. Theodorson, istilah intelektual adalah: Those members of society who are devoted to development of original ideas and are engaged in creative intellectual pursuits. The intellectuals constitute a small, creative segment of the intellegentia. They provide the intellectual leadership for the remainder of the intellegentia. ${ }^{5}$ Maksudnya yaitu intelektual adalah anggota masyarakat yang mengabdikan diri kepada pengembangan gagasan-gagasan atau ide-ide yang orisinal dan terlibat dalam usaha-usaha intelektual kreatif. Kaum intelektual merupakan sebuah segmen yang kreatif dari lapisan intelegensia. Mereka memberikan kepemimpinan intelektual kepada lapisan intelegensia lainnya.

Menurut Mohammad Hatta dalam Azyumardi Azra, "kaum intelegensia adalah bagian dari rakyat, warga negara yang sama-sama mempunyai hak dan kewajiban. Dalam Indonesia yang berdemokrasi, ia ikut serta bertanggunjawab tentang perbaikan nasib bangsa. Dan sebagai warga negara yang terpelajar, yang tahu menimbang buruk dan baik, yang tahu menguji benar dan salah dengan pendapat yang beralasan, tanggungjawabnya seperti saya katakan tadi adalah intelektual dan moril."

Azyumardi Azra berpendapat bahwa "intelektual tidaklah identik dengan intelegensia, tidak setiap tamatan universitas (intelegensia) itu intelektual, karena kesempitan wawasan pikiran dan pandangannya kepada profesi dan hal-hal teknis. Intelektual boleh jadi bukan berasal dari lulusan universitas. Bisa jadi tamatan sekolah rendah yang mampu mengembangkan pikiran dan concern-nya secara otodidak, misalnya ulama, filosof, seniman dan lain-lain. Mereka ini mampu berpikir bebas, mencakup pengamatan yang cermat terhadap gejala-gejala di suatu lingkungan, pemahaman tentang sebab-sebab gejala itu dan korelasinya dengan gejala lain, pada akhirnya perumusan suatu kesimpulan yang dapat dikomunikasikan kepada orang lain dalam bahasa yang jelas."7

Jadi, dapat disimpulkan bahwa intelektual adalah orang yang mempunyai kecerdasan pikiran, cerdik pandai, bijaksana, berilmu, berakal dan berakhlak baik

\footnotetext{
${ }^{3}$ AS. Hornby, EV. Gatenby, H. Wakefield, The Advenced Learner's Dictionary of Current English, (Oxford: Secon Edition, 1962), h. 513.

${ }^{4}$ John M. Echol dan Hassan Shadily, Kamus Inggris Indonesia, (Jakarta: Gramedia, 1981), h. 326

${ }^{5}$ George A. Theodorson and Achilles Theodorson, A Modern Dictionary of Sociology, (New York: Barner and Noble Books, 1979), h. 210.

${ }^{6}$ Azyumardi Azra, Isei-Isei Intelektual Muslim dan Pendidikan Islam, (Jakarta: Logos Wacana Ilmu, 1998), h. 33.

${ }^{7}$ Azyumardi Azra, Isei-Isei Intelektual Muslim ..., h. 34.
} 
serta profesional dalam bidangnya sehingga bisa menjadi pemimpin dalam masyarakat untuk mengembangkan nilai-nilai budaya.

\section{HUBUNGAN AWAL INDONESIA DENGAN TIMUR TENGAH}

Hubungan awal antara Indonesia dan Timur Tengah sudah mulai terjadi sejak kedatangan Islam di Indonesia. Ada beberapa teori tentang kedatangan Islam di Nusantara, yaitu: Pertama, Teori dari Belanda yaitu Pijnappel, ahli dari Universitas Leiden yang didukung oleh Snouck Hurgronje, bahwa asal muasal Islam dibawa dari Anak Benua India dengan alasan terdapat kesamaan antara mazhab orang-orang Arab yang ada di Gujarat dan Malabar dengan mazhab di Nusantara, yakni bermazhab Syafi'i. Moquette menambahkan bahwa ada kemiripan bentuk batu nisan di Pasai, kawasan utara Sumatera, khususnya yang bertanggal 17 Zulhijah 831 H/27 September 1428 M dan di Makam Maulana Malik Ibrahim (w. 822/1419) di Gresik, Jawa Timur dengan bentuk batu nisan yang terdapat di Cambay, Gujarat. ${ }^{8}$

Kedua, teori Marrison berpendapat bahwa Islam di Nusantara dibawa para penyebar Muslim dari Pantai Coromandel akhir abad ke-13, bukan dari Gujarat. Arnold menambahkan Islam dibawa ke Nusantra antara lain juga dari Coromandel dan Malabar karena kesamaan mazhab fikih di kedua wilayah tersebut, yaitu mazhab Syafi'i. Menurut Arnold, para pedagang dari Coromandel dan Malabar memiliki peranan penting dalam perdagangan antara India dan Nusantara, mereka tidak hanya terlibat dalam perdagangan tettapi juga terlibat dalam penyebaran Islam. ${ }^{9}$

Ketiga, teori Crawfurd bahwa Islam langsung dibawa dari Arabia, walaupun ia menyatakan bahwa interaksi penduduk Nusantara dengan kaum Muslim yang berasal dari pantai timur India merupakan faktor penting dalam penyebaran Islam di Nusantara. Keempat, teori Keijzer, menyatakan bahwa Islam di Nusantara berasal dari Mesir dengan alasan pertimbangan kesamaan mazhab antara penduduk Muslim di kedua wilayah tersebut yaitu bermazhab Syafi'i. Teori Arab ini juga didukung oleh Niemann dan de Hollander yang memandang Hadhramawt sebagai sumber Islam di Nusantara. ${ }^{10}$ Kelima, teori terakhir ini dipegang oleh A.H. Johns, menyampaikan bahwa Islam datang ke Nusantara melalui peran penting dari para pedagang dalam penyebaran dan para sufi yang terutama melakukan penyiaran Islam di wilayah ini pada abad ke-13, hal ini berdasarkan sejarah literatur MelayuIndonesia. $^{11}$

Menurut Azyumardi Azra, hubungan antara Nusantara dengan Timur Tengah melibatkan sejarah yang panjang, yang dapat dilacak sampai masa yang sangat tua (antiquity). Kontak paling awal antara kedua wilayah ini, khususnya

\footnotetext{
${ }^{8}$ Azyumardi Azra, Jaringan Ulama Timur Tengah dan Kepulauan Nusantara ..., h. 3.

${ }^{9}$ Azyumardi Azra, Jaringan Ulama Timur Tengah dan Kepulauan Nusantara ..., h. 6.

${ }^{10}$ Azyumardi Azra, Jaringan Ulama Timur Tengah dan Kepulauan Nusantara ..., h. 8.

${ }^{11}$ Azyumardi Azra, Jaringan Ulama Timur Tengah dan Kepulauan Nusantara ..., h. 14.
} 
berkaitan dengan perdagangan, bermula sejak masa Phunisia dan Saba. Pengenalan dan penyebaran Islam di pesisir pantai anak benua India terbukti merangsang tidak hanya hubungan dagang antara Timur Tengah dengan Nusantara tetapi juga berbagai bentuk hubungan dan pertukaran (exchanges) keagamaan, sosial, politik dan kebudayaan. ${ }^{12}$ Jadi dapat disimpulkan bahwa hubungan awal antara Indonesia dengan Timur Tengah dimulai sejak pertama sekali masuknya Islam ke Indonesia yang dibawa oleh para pedagang dari Arab dan Mesir sesuai dengan teori ke tiga dan ke empat.

\section{HUBUNGAN KESULTANAN NUSANTARA DENGAN TIMUR TENGAH}

Teori Arabia menyebutkan bahwa Islam sudah masuk ke Indonesia pada abad ke-7 M, pada awal abad pertama Hijriah. Islam masuk ke Indonesia langsung dari Mekah atau Madinah. Ketika itu, pemerintahan Islam masih berada di bawah pimpinan Khulafaur Rasyidin. Dalam sumber literatur Cina, disebutkan bahwa menjelang per empat pertama abad ke-7 M, banyak terdapat perkampungan ArabMuslim di pesisir pantai Sumatra. Di sinilah orang Arab tinggal dan menikah dengan penduduk lokal, kemudian membentuk komunitas Muslim, sehingga terjadi proses Islamisasi. Setelah terjadi proses Islamisasi, maka muncullah kerajaankerajaan di Indonesia seperti Samudra Pasai, Malaka, Banten dan Mataram. Kemudian Pendidikan Islam dimulai oleh para mubaliq dalam bentuk pendidikan informal. Pergaulan kependidikan antara mubaliq dan masyarakat, merupakan inti pokok dari proses pendidikan. Setelah masyarakat Muslim terbentuk, mereka membutuhkan tempat ibadah seperti masjid atau langgar, dan membutuhkan lembaga pendidikan seperti pesantren, surau dan dayah sebagai tempat proses pendidikan.

Dengan berdirinya kerajaan-kerajaan Islam pada abad ke-13, hubungan dengan Timur Tengah menjadi semakin mapan. Kehadiran ulama dari Timur Tengah dan dunia Islam yang lebih besar, khususnya Makkah, merupakan langkah penting dalam memperkenalkan Islam di Nusantara. Sumber-sumber lokal mengasalkan Islamisasi wilayah tersebut kepada datangnya ulama Makkah. Sebagai contoh Hikayat Raja-Raja Pasai, menggambarkan kedatangan seorang ulama dari Makkah, Syaikh Ismail, ke Kerajaan Samudera Pasai untuk menyebarkan Islam. ${ }^{13}$

Seiring dengan semakin tingginya frekuensi kunjungan para duta Muslim ke wilayah Cina melalaui jalur Selat Malaka, pengaruh Islam semakin meluas. Wilayah yang dilalui oleh para duta Muslim itu pun menjadi basis utama munculnya kekuatan politik Islam di Indonesia. Sebagai contoh adalah Kesultanan Perlak dan Pasai atau Aceh, termasuk juga Kesultanan Johor dan Malaka yang berada di Semenanjung Malaysia. Hubungan kesultanan ini, dengan pusat

\footnotetext{
${ }^{12}$ Azyumardi Azra, Jaringan Ulama Timur Tengah dan Kepulauan Nusantara ..., h. 20.

${ }^{13}$ Jajat Burhanuddin, Ulama dan Kekuasaan: Pergumulan Elit Muslim dalam Sejarah Indonesia, (Jakarta: Mizan Publika, 2012), h. 29.
} 
kekuasaan Islam di kawasan Timur Tengah adalah sebuah realita politik dan sejarah. Hubungan tersebut semakin erat pada masa Turki Utsmani. Munculnya Turki Utsmani sebagai wujud pemerintahan Islam yang berhasil melakukan futuhat (penaklukan) atas Konstatinopel (yang merupakan ibu kota Kerajaan Romawi Timur pada 857 H/1453 M) menyebabkan nama Turki melekat di hati umat Islam Indonesia. Nama yang popular bagi penguasa Turki Utsmani di Indonesia adalah "Sultan Rum". Sebelum kebangkitan Turki Utsmani, istilah "Rum" mengacu kepada Bizantium dan kadang-kadang juga pada Kerajaan Romawi. Akan tetapi, setelah kemunculan Turki Utsmani, istilah "Rum" beredar untuk menyebut Kesultanan Turki Utsmani. Sejak saat itu, supremasi politik Rum (Turki Utsmani) menyebar ke berbagai wilayah di dunia Islam, termasuk ke Indonesia. ${ }^{14}$

Islam didakwahkan dan disebarkan oleh para pedagang dan para ulama yang memang berniat datang atau ditugaskan untuk mengajarkan ajaran tauhid. Tidak hanya para ulama dan pedagang yang datang ke Indonesia, orang-orang Indonesia pun banyak pula yang mendalami Islam dan datang langsung ke sumbernya, terutama Mekkah atau Madinah. Kapal-kapal dan ekspedisi dari Aceh terus berlayar menuju Timur Tengah pada awal abad ke 16-M. Bahkan pada tahun 974 Hijriah atau $1566 \mathrm{M}$, dilaporkan ada lima kapal dari Kesultanan Asyi (Aceh) yang berlabuh di Bandar pelabuhan Jeddah. Ukhuwah yang terjalin erat antara Aceh dan kekhalifahan Islam, membuat Aceh mendapat sebutan Serambi Mekah. Puncak hubungan baik antara Aceh dengan pemerintah Islam terjadi pada masa kekhalifahan Turki Utsmani, tidak hanya dalam hubungan dagang dan keagamaan, tetapi juga hubungan politik dan militer. Pemerintah Utsmani pernah membantu mengusir Parangi (Portugis) dari perairan yang akan dilalui Muslim Aceh yang hendak menunaikan ibadah haji ke tanah suci. ${ }^{15}$

Selain di Pulau Sumatera, dakwah Islam juga dilakukan dalam waktu yang bersamaan di Pulau Jawa. Menurut Hamka dalam bukunya Sejarah Umat Islam dalam buku Sulasman \& Suparman menyatakan bahwa, Pada tahun 674-675 M, duta dari orang-orang Ta Shih (Arab) untuk Cina adalah sahabat Rasulullah SAW., yaitu Muawiyah bin Abi Sufyan, yang secara diam-diam meneruskan perjalanan hingga ke Pulau Jawa. Muawiyah yang juga pendiri kekhalifahan Islam Bani Umayyah, menyamar sebagai pedagang dan menyelidiki kondisi tanah Jawa saat itu. Ekspedisi ini mendatangi kerajaan Kalingga dan melakukan pengamatan. Sehingga tanah Jawa menjadi kekuatan Islam yang cukup besar pada masa-masa berikutnya dengan Kesultanan Giri, Demak, Pajang, dan Mataram, bahkan hingga Banten dan Cirebon.

Peranan Walisongo dalam perjalanan kerajaan-kerajaan Islam di Jawa tidak bisa dipisahkan. Merekalah yang menyiapkan pondasi yang kuat, yang selanjutnya dibangun pemerintahan Islam yang berbentuk kesultanan. Kesultanan Islam yang

\footnotetext{
${ }^{14}$ Azyumardi Azra, Jaringan Ulama Timur Tengah dan Kepulauan Nusantara ..., h.36.

${ }^{15}$ Sulasman dan Suparman, Jejak Islam di Asia \& Eropa: Dari Masa Klasik Hingga Masa Modern, (Bandung: Pustaka Setia, 2013), h. 302.
} 
terkenal di tanah Jawa seperti Kesultanan Demak, dan Kesultanan Giri. Wilayah Giri, Gresik dan Jawa Timur dibangun menjadi kekuasaan agama dan pusat pengaderan dakwah. Dari wilayah Giri, dihasilkan pendakwah yang telah dikirim ke kawasan Nusa Tenggara dan wilayah timur Indonesia lainnya. Buya Hamka menyebutkan, "Sedemikian besarnya pengaruh kekuatan agama yang dihasilkan Giri, Majapahit yang kala itu menguasai Jawa tidak punya kuasa untuk menghapus kekuatan Giri”.

Para Walisongo adalah intelektual yang menjadi pembawa perubahan bagi masyarakat pada masanya. Walisongo terdiri dari Maulana Malik Ibrahim, Sunan Ample, Sunan Bonang, Sunan Drajat, Sunan Kudus, Sunan Giri, Sunan Kalijaga, Sunan Muria, dan Sunan Gunung Jati. ${ }^{16}$ Pengaruh mereka terasa dalam beragam bentuk manifestasi peradaban baru masyarakat Jawa, mulai dari kesehatan, bercocok tanam, perniagaan, kebudayaan, kesenian, kemasyarakatan, hingga pemerintahan.

\section{HUBUNGAN INTELEKTUAL KEAGAMAAN ISLAM DI INDONESIA DENGAN TIMUR TENGAH}

Mekkah dan Madinah di Timur Tengah menjadi tempat pertemuan terbesar kaum Muslim dari berbagai penjuru dunia untuk melakukan ibadah haji. Haramayn adalah pusat intelektual dunia Muslim yaitu ulama, sufi, filsuf, penyair, pengusaha dan sejarawan Muslim bertemu dan saling menukar informasi. Inilah yang menjadi latar belakang mengapa ulama dan penuntut ilmu yang mengajar dan belajar di Mekkah dan Madinah pada umumnya memiliki pandangan keagamaan lebih luas dibandingkan dengan tempat-tempat lain. Menurut azyumardi Azra, akselerasi hubungan-hubungan antara Indonesia dengan Timur Tengah memberi sumbangan signifikan kepada pertumbuhan jumlah jamaah haji Melayu-Indonesia di Haramayn, yang pada gilirannya memacu keterlibatan mereka di dalam jaringan ulama yang ada. ${ }^{17}$

Kebangkitan keilmuan Sunni yang pada gilirannya, mendorong pertumbuhan madrasah sebagai lembaga pendidikan tipikal Muslim. Pendidikan dilakukan dalam halaqah, majlis al-tadris, dan kuttab. Salah satu tanda bangkitnya keilmuan Haramayn adalah berdirinya madrasah yang dipengaruhi oleh madrasah di tempat-tempat di wilayah Timur Tengah. Kemajuan dibidang ilmu dan perdagangan di Haramayn terus meningkatkan kuantitas ulama yang datang ke Haramayn. Demikian pula jumlah jamaah haji juga terus bertambah dikarenakan Jeddah sebagai pelabuhan Internasional.

Islam di Indonesia tidak dapat dipisahkan dengan Islam di Timur Tengah. Sudah sejak lama terjadi hubungan antara Timur Tengah dan Nusantara dalam bentuk jaringan intelektual. Menurut Jajat, Hubungan dengan Timur Tengah menjadi lebih kuat di Kerajaan Aceh pada abad ke-17. Hubungan ini dibuktikan

\footnotetext{
${ }^{16}$ https://id.wikipedia.org/wiki/Walisongo

${ }^{17}$ Azyumardi Azra, Jaringan Ulama Timur Tengah dan Kepulauan Nusantara ..., h. 55.
} 
dengan terbentuknya sebuah jaringan ulama, yang kemudian membuat Makkah memainkan peranan penting dalam diskursus intelektual di Nusantara pada periode tersebut. ${ }^{18}$ Hubungan intelektual dilakukan oleh para ulama terkait dengan paham keagamaan. Setelah belajar di pusat jaringan keagamaan di Timur Tengah, para ulama Melayu Indonesia sejak paruh ke dua abad ke 17 dan seterusnya melakukan usaha-usaha untuk menyebarkan ide-ide baru di Indonesia. Ide-ide tersebut yaitu menyebarkan Neo-sufisme di Indonesia.

Sejarah pertumbuhan jaringan antara penuntut ilmu dari Indonesia dengan banyak ulama Timur Tengah, khususnya Haramayn, melibatkan proses-proses historis yang amat kompleks. Jaringan murid-guru yang tercipta di antara kaum Muslimin, baik dari kalangan penuntut ilmu dan ulama maupun muslim awam umumnya diantara kedua kawasan dunia Muslim ini merupakan buah dari interaksi yang panjang di antara wilayah Muslim di Indonesia dan Timur Tengah. Proses historis yang terjadi dalam perjalanan Islam di Nusantara dalam hubungannya dengan perkembangan Islam di Timur Tengah, bisa dilacak sejak masa-masa awal kedatangan dan penyebaran Islam di Nusantara sampai kurun waktu yang demikian panjang. Kebangkitan keilmuan serta jaringan ulama di Haramayn melalui berdirinya madrasah, ribath, dan zawiyyah. Serta para jama'ah haji dan para pedagang yang datang ke Haramayn tidak hanya menunaikan kewajibanya tapi belajar dan mengajar disana.

Timur Tengah dan Kepulauan Nusantara abad ke 17 dan 18 disebut sebagai awal penyebaran pembaharuan Islam Nusantara. Sejak terjadinya interaksi kaum muslimin Timur Tengah dengan Nusantara sampai akhir abad ke 18, banyak kontinuitas dalam hubungan antara kaum Muslimin di kedua wilayah ini. Pada awalnya hubungan itu lebih berbentuk hubungan ekonomi dan dagang, kemudian disusul hubungan politik-keagamaan, dan untuk selanjutnya hubungan intelektual keagamaan. ${ }^{19}$ Pada abad ke-17, Tiga ulama yang menjadi mata rantai utama dari jaringan ulama di wilayah Melayu-Indonesia serta membawa ajaran Neo-Sufisme (keselarasan antara Tasawuf dan Syariat) adalah berawal dari al-Raniri, al-Sinkili berkembang di kesultanan Aceh dan al-Maqassari lahir di Sulawesi yang memulai karirnya di Banten Jawa Barat. ${ }^{20}$ Karir dan ajaran-ajaran ulama ini dengan jelas menunjukkan, bahwa perkembangan Islam di Indonesia sangat terpengaruh oleh perkembangan di Timur Tengah.

Sedangkan pada abad ke-18, ada beberapa ulama yang membawa pembaruan kembali ke ortodoks Sunni yang berperan penting di Nusantara, antara lain: Abd Samad Al-Palimbani (Palembang, Sumatera Selatan), Muhammad Muhyi Al-Din bin Syihab Al-Din (Palembang), Muhammad Arsyad al-Banjari (Kalimantan Selatan), Muhammad Nafis al-Banjari (Kalimantan Selatan), Abd al-

\footnotetext{
${ }^{18}$ Jajat Burhanudin, Ulama dan Kekuasaan..., h. 30.

${ }^{19}$ Azyumardi Azra, Jaringan Ulama Timur Tengah dan Kepulauan Nusantara ..., h. 1.

${ }^{20}$ Azyumardi Azra, Jaringan Ulama Timur Tengah dan Kepulauan Nusantara ..., h. 205.
} 
Wahhab al-Bugisi (Sulawesi), Dawud bin Abd Allah al-Fatani (Patani, Thailan Selatan). ${ }^{21}$

Timbulnya pembaharuan pemikiran Islam di Indonesia baik dalam bidang agama, sosial dan pendidikan diawali dan dilatarbelakangi oleh pembaruan pemikiran Islam yang timbul di belahan dunia Islam lainnya, terutama diawali oleh pembaruan pemikiran Islam yang timbul di Mesir dimulai sejak kedatangan Napoleon ke Mesir. Napoleon mendirikan sebuah lembaga ilmiah yang diberi nama Institut d Egypt. Lembaga ini memiliki empat bidang kajian pokok, yaitu kajian ilmu pasti, ilmu alam, ekonomi politik, sastra, dan seni. Perlengkapan yang ada dalam lembaga ini yaitu mesin cetak, teleskop, mikroskop, dan alat-alat percobaan kimiawi. $^{22}$

Peristiwa ini menimbulkan kesadaran umat Islam mengubah diri, oleh karena itu muncullah di dunia Islam tokoh-tokoh yang menyesuaikan diri dengan perkembangan kemajuan zaman. Muhammad Ali Pasha adalah orang yang banyak mendirikan lembaga-lembaga pendidikan umum seperti sekolah militer, teknik dan kedokteran, sekolah pertambangan di Mesir, juga menggalakkan penerjemahan buku-buku dari bahasa Eropa ke Bahasa Arab. Di Turki Muncul Sultan Mahmud II yang juga banyak mendirikan lembaga pendidikan umum, seperti sekolah militer, sekolah teknik, kedokteran pembedahan pada tahun 1838. Said Ahmad Khan juga mendirikan lembaga pendidikan MOAC yang sekarang menjadi universitas Aligarh di India.

Pendidikan Islam pada masa kerajaan bersifat relatif terbatas pada ilmuilmu keagamaan dan bersifat kosmopolitan. Kosmopolitan maksudnya bahwa aktivitas intelektual di Indonesia memiliki jaringan yang luas ke berbagai wilayah dunia Islam lainnya. Sejumlah nama besar intelektual Indonesia pada zaman kerajaan adalah merupakan ilmuan pendatang dari dunia Arab, Persia dan India. Sebaliknya sejumlah yang lain adalah para ilmuan tempatan yang mendapatkan pendidikan dibelahan dunia lain dan kemudian kembali ke Indonesia. Hal ini secara baik ditunjukkan oleh kajian-kajian sejarah terhadap berbagai kerajaan Islam Indonesia. Adapun nama-nama dari para ulama yang meramaikan wacana intelektual Indonesia pada masa kerajaan adalah Al-Qadhi al-Syarif Amir alSyirazi, Taj al-Din al-Isfahani, Hamzah al-Fansuri, Abd al-Ra'uf al-Sinkili, Abd alShamat al-Falimbani, Syams al-Din al-Samatrani, Yusuf al-Maqassari, Nuruddin al-Raniri, atau Nawawi al-Bantani. ${ }^{23}$

Dengan watak kosmopolitan, maka adanya interaksi dan saling berpengaruh antara wacana intelektual Islam di dunia Arab, Persia, India dan Indonesia dalam intensitas yang cukup tinggi. Azyumardi Azra telah melakukan penelitian yang

\footnotetext{
${ }^{21}$ Azyumardi Azra, Jaringan Ulama Timur Tengah dan Kepulauan Nusantara ..., h. 316.

${ }^{22}$ Haidar Putra Daulay, Sejarah Pertumbuhan dan Pembaharuan Pendidikan Islam di Indonesia, (Kencana, Prenada Media Group, Jakarta, 2007), h. 39.

${ }^{23}$ Hasan Asari, Sejarah Pendidikan Islam: Membangun Relevansi Masa Lalu dengan Masa Kini dan Masa Depan, (Medan: Perdana Publishing, 2019), h. 101.
} 
sangat komprehensif tentang hubungan pembaruan pemikiran Islam di Nusantara dengan perkembangan pemikiran di Timur Tengah. Dia menjelaskan bahwa menjelang paruh ke dua abad ke-17, hubungan-hubungan keagamaan dan politik juga dijalin dengan para penguasa Haramayn. Muslim Nusantara semakin banyak ke tanah suci, yang pada gilirannya mendorong terciptanya jalinan keilmuan antara Timur Tengah dengan Nusantara melalui ulama Timur Tengah dan murid-murid Jawi. $^{24}$

Jaringan lembaga pendidikan yang dilaksanakan, bukan saja sebagai motor bagi terjadinya transformasi ilmu, tetapi juga bagi lahirnya cikal bakal sosok ulama era selanjutnya. Perkembangan lembaga pendidikan ini dilatarbelakangi oleh animo masyarakat yang demikian besar terhadap perkembangan pendidikan dan juga pengaruh dari penguasa yang memberikan kebebasan bagi masyarakat mengembangkan pendidikannya dan persentuhan Islam dengan budaya bangsabangsa lainnya.

Lembaga pendidikan merupakan sarana yang strategis bagi proses terjadinya transformasi nilai dan budaya pada suatu komunitas sosial. Kehadiran lembaga pendidikan telah memberikan andil yang sangat besar bagi pengembangan ajaran yang terdapat dalam Al-Qur'an dan Hadis. Pelacakan eksistensi lembaga pendidikan Islam tidak bisa dilepaskan dari proses masuknya Islam di Minangkabau yang bernuansa mistis (tarekat) dan mengalami akulturasi dengan budaya lokal (adat). Kemunculan lembaga pendidikan Islam dalam sebuah komunitas, tidak mengalami ruang hampa, akan tetapi senantiasa dinamis, baik dari fungsi maupun sistem pembelajarannya. Selanjutnya kehadiran lembaga pendidikan Islam, telah memberikan spektrum tersendiri dalam membuka wawasan dan dinamika intelektual umat Islam. Melalui lembaga pendidikan Islam, seperti surau tradisional telah melahirkan sejumlah ulama dan pemimpin bangsa. ${ }^{25}$ Dinamika pemikiran dan kemunculan lembaga pendidikan Islam era awal, telah memberikan andil yang sangat besar bagi membangun sikap nasionalisme dan dinamika intelektual umat yang selama ini terbelenggu untuk mengembangkan ilmu pengetahuan.

\section{TOKOH INTELEKTUAL INDONESIA YANG PERNAH BELAJAR DI TIMUR TENGAH}

Banyak sekali para tokoh intelektual Muslim yang berasal dari Indonesia belajar ke Timur Tengah, dan kembali ke Indonesia untuk membawa perubahan intelektual keagamaan Islam di Indonesia. Namun, disini penulis hanya memperkenalkan beberapa tokoh intelektual Muslim saja yang pernah belajar di Timur Tengah, yaitu:

\section{Nur al-Din al-Raniri (w. 1068/1658)}

\footnotetext{
${ }^{24}$ Azyumardi Azra, Jaringan Ulama Timur Tengah dan Kepulauan Nusantara ..,h. 51

${ }^{25}$ Samsul Nizar, Sejarah dan Pergolakan Pemikiran Pendidikan Islam: Potret Timur Tengah Era Awal dan Indonesia, (Ciputat: Ciputat Press Group, 2005), h. 68-69
} 
Al-Raniri adalah ulama pertama dalam jaringan dengan Timur Tengah di abad ke-17. Dia dilahirkan di Ranir, sebuah kota pelabuhan tua di pantai Gujarat. Setelah memperoleh pendidikan di kota kelahirannya, al-Raniri melanjutkan pendidikannya di Makkah dan Hadramaut. Disana dia bergabung dengan lingkaran komunitas Jawi, yang menumbuhkan kebanggaannya sebagai keturunan Melayu, karena ibu al-Raniri adalah seorang Melayu. Salah satu gurunya yang terkenal dalam hubungan intelektual adalah Abu Hafs Umar bin Abdullah Ba Syaiban alTarimi al-Hadramani (w 1656). Gurunya tersebut mengarahkan untuk tidak hanya terlibat dalam lingkungan pergaulan sufisme, tetapi juga memiliki hubungan dengan Nusantara. Ba Syaiban adalah salah seorang sarjana yang memainkan peranan penting dalam menyalurkan ide-ide keagamaan dari Timur Tengah ke Nusantara. ${ }^{26}$

Al-Raniri dianggap sebagai tokoh sufi ketimbang seorang pembaru (mujaddid). Tidak ada keterangan sampai kapan dia menghabiskan waktu di Makkah dan Hadramaut, tapi kemungkinan besar, dia langsung pergi ke Haramayn, karena dalam pandangan al-Hasani, dia berada disana pada 1030/1620 atau 1031/1621 untuk menunaikan ibadah haji, sehingga dia menjalin hubungan dengan murid-murid dan jamaah haji Jawi sebelum kembali ke Gujarat._Tidak ada informasi kapan al-Raniri melakukan perjalanan pertama dan menetap di wilayah Melayu. Pada tahun 1047/1637, dia tinggal di Kepulauan Nusantara dan mendapatkan jabatan Syaikh al-Islam di Kesultanan Aceh pada tahun yang sama.Setelah memperoleh posisi kuat di Istana Sultan Aceh, al-Raniri melancarkan pembaruan Islamnya di Aceh. Al-Raniri berpandangan, satu masalah dasar pada kaum Muslim Melayu-Indonesia adalah landasan keimanan, karena itu dia berusaha menerangkan, antara lain, hubungan antara hakikat Tuhan dengan alam raya serta manusia, perbedaan antara Tuhan dan alam raya, asal-muasal dunia dalam masa dan transendensi mutlak Tuhan vis a vis manusia. ${ }^{27}$

\section{Abd al-Ra'uf al-Sinkili (1024-1105/1615-930)}

Pembaruan setelah al-Raniri di Nusantara di lanjutkan oleh al-Sinkili. Koneksi al-Sinkili dengan ulama Haramayn melebihi al Raniri. Al-Sinkili seorang muslim asal Fansur, Sinkil di wilayah barat laut Aceh. Al-Sinkili diperkirakan berangkat dari Aceh ke Arabia tahun 1052/1642. Jumlah guru al-Sinkili 19 orang dan 27 ulama lain yang memiliki hubungan kontak pribadi. Salah satu guru alSingkili di Hijaz adalah ulama neo-sufi terkemuka bernama Ibrahim al-Kurani (1614-1690) dan Ahmad al-Qusyasyi (1538-1661). Kota-kota tempat al-Sinkili menuntut ilmu adalah Dhuha (wilayah teluk Persia), Jeddah, Makkah dan akhirnya Madinah. Muridnya yang terkenal adalah Burhanudin dari Ulakan di Sumatera Barat yang mendirikan surau, lembaga pendidikan sufi di Ulakan, menjadi basis

\footnotetext{
${ }^{26}$ Jajat Burhanudin, Ulama dan Kekuasaan..., h. 31.

${ }^{27}$ Azyumardi Azra, Jaringan Ulama Timur Tengah dan Kepulauan Nusantara ..,h. 205237.
} 
Islamisasi di Minangkabau, Sumatera Barat. Selain itu Abdul Muhyi dari Pamijahan, Jawa Barat. ${ }^{28}$

Adapun pembaruan dan pemikiran al-Sinkili mempunyai empat langkah, yaitu fikh muamalat, tafsir, hadits dan tasawuf. Langkah pertama, pembaruan beliau mengenai fikh melalui karya Mir'at al-Thullab, yang tidak hanya menerangkan pada ibadah tapi mencakup seluruh aspek kehidupan sehari-hari. Yang kedua, beliau alim pertama yang bersedia mempersiapkan tafsir lengkap al Qur'an dalam bahasa Melayu (Tarjamun al-Mustafid). Riddell dan Harun menegaskan karya ini terjemah dari kitab Tafsir Jalalayn karya Jal al Din al Mahlli dan Jalal al Din al Suyuthi. Hanya saja pada bagian-bagian tertentu saja, al-Sinkili juga memanfaatkan tafsir al-Baydhawi dan al-Khazim. Ketiga, melalui karyanya di bidang hadis. Yaitu penafsiran hadist Arba'in karya al-Nawawi dan yang kedua al Mawa'izh al Badi'ah sebuah koleksi Hadits Qudsi. Dengan karya beliau ini, suatu perhatian yang sungguh-sungguh bagi kaum muslim yang awam, yang dikehendaki hanyalah mengajak mereka menuju pemahaman lebih baik atas ajaran-ajaran Islam. Keempat, pembaruan beliau dibidang ilmu kalam dan tasawuf. Dalam ajaran mistisnya melalui Kifayat al-Muhtajin ila Masyrab al-Muwahhidin al-Qa'ilin bi Wahdat al-Wujud, mempertahankan transendensi Tuhan atas ciptaan-Nya. Beliau menolak Wujudiyah yang menekankan imanensi Tuhan dalam ciptaan-Nya.

Dari karya dan ajaran al-Sinkili dapat disimpulkan bahwa beliau secara sadar turut menyebarkan doktrin dan kecenderungan intelektual dan praktis dalam jaringan ulama untuk memperkuat tradisi Islam di kepaulauan Melayu Indonesia. Ciri dari ajarannya adalah Neo-Sufisme. Karya menunjukkan bahwa tasawuf harus berjalan sesuai dengan syariat. Adapun pendekatan yang dipakai al-Sinkili dalam pembaruan bergaya evolusioner bukan radikal. ${ }^{29}$

\section{Muhammad Yusuf al-Maqassari (1037-1111/1627-99)}

Muhammad Yusuf bin Abd Allah Abu al-Mahasin al-Taj al-khalwati alMaqassari dilahirkan dari keluarga Muslim, memulai perjalanannya dari Sulawesi Selatan, Jawa Barat, Arabia, Sri Langka dan Afrika Selatan. Beliau mendapatkan pendidikan Islam dari kalangan sufi, bermula belajar membaca al-Qur'an ke Daeng ri Tasammang, kemudian belajar Bahasa Arab, Fikh, Tauhid dan Tasawuf ke Sayyid Ba Alwi bin Abd Allah al-Allamah al-Thahir. Setelah itu melajutkan ke Cikoang untuk belajar. Dari tempat ini Maqassari menikah dengan puteri Sultan Gowa. Setelah itu al Maqassari meninggalkan Makasar menuju Arabia untuk belajar pada bulan Rajab 1054/September 1644.

Beliau menuju Arabia memanfaatkan rute perdagangan interinsuler dengan beberapa singgah sebelum sampai ke Arabia, yaitu: Pertama, Banten. Ada kemungkinan dia belajar juga disana dan membangun jalinan yang kuat dengan

\footnotetext{
${ }^{28}$ Jajat Burhanudin, Ulama dan Kekuasaan..., h. 33-35.

${ }^{29}$ Azyumardi Azra, Jaringan Ulama Timur Tengah dan Kepulauan Nusantara .., h. 238269.
} 
orang-orang kerajaan termasuk Putra Mahkota Pangeran Surya. Kedua, dari Banten menuju ke Aceh, dalam karya Maqassari Safinat al-Najah sebelum menyebutkan silsilah lengkah tarekat al-Qadiriyah bahwa beliau mengambil tarekat ini ke Syaikh Jaylani dikenal dengan Syaikh Nuruddin bin Masanji bin Muhammad Hamid alQuraisy al-Raniri. Dari keterangan tersebut beliau mengikuti al-Raniri ke India. Ketiga, sebelum ke Haramayn al-Maqassari mampir terlebih dahulu ke Yaman. Di Yaman di daerah Zabid beliau belajar pada Muhammad bin Abd al-Baqi alNaqsyabandi, Sayyid Ali al-Zabidi, dan Muhammad bin al-Wajih al-Sa'di alYamani. Setelah beberapa tahun di Yaman beliau melanjutkan ke Haramayn. Di Haramayn beliau belajar pada al-Kurani, al-Qusyasyi, Muhammad al-Mazru', Muhammad Mirza dan beberapa guru lainnya.

Setelah dari Haramayn al-Maqassari tidak langsung kembali ke Nusantara tetapi mampir di Damaskus yang disarankan oleh Muhammad Mirza dan Ahmad Qusyasyi. Beliau belajar disana pada Ayyub al-Khalwati seorang ulama terkemuka tentang ilmu-ilmu eksoteris dan esoteris. Setelah itu ke Istanbul kemudian kembali ke Melayu Indonesia. Adapun pembaruannya, dalam konsep tasawuf adalah pemurnian kepercayaan pada keesaan Tuhan. Dia menekankan bahwa keesaan Tuhan itu tak terbatas dan mutlak. Tauhid adalah komponen penting dalam Islam. Lebih jauh dia membandingkan tauhid murni dengan sebuah pohon berdaun: pengetahuan makrifat adalah cabang dan daunnya, sedangkan ibadah adalah buahbuahnya. Orang yang tidak memiliki makrifat, bodoh dan orang tidak melakukan ibadah, fasiq.

Beliau sufi tapi taat syariat dan tidak mengasingkan diri dari masyarakat. Teologi al-Asy'ariyyah lah yang dipegang oleh al-Maqassari. Terkait dengan kepercayaan kepada Tuhan, al-Maqassari membaginya kedalam 4 kelompok: 1) orang yang hanya mengucapkan syahadat tapi tidak benar-benar beriman (munafiq). 2) orang yang mengucapkan syahadat tetapi juga menanamkannya ke dalam jiwa (orang awam). 3) orang yang benar-benar paham akan implikasi lahir dan batin dari pernyataan keimanannnya (orang-orang elit). 4) orang-orang dari golongan ketiga yang mengintensifkan syahadah mereka dengan mengamalkan tasawuf (orang terpilih dari golongan elite). ${ }^{30}$

\section{4. 'Abd al-Shamad al-Palimbani (1116-1244/1704-1828)}

'Abd al-Shamad al-Palimbani adalah ulama Palembang yang paling menonjol. Ia paling berpengaruh diantara para ulama yang berasal dari Palembang, terutama karya-karyanya yang beredar luas di Indonesia. Ia mempunyai karier terhormat di Timur Tengah. Nama asli al-Palimbani yaitu 'Abd al-Shamad bin 'Abd al-Rahman al-Jawi, ia lahir sekitar 1116/1704 di Palembang dan ayahnya adalah seorang sayid, dan ibunya seorang wanita Palembang. Dia meninggal dunia setelah

${ }^{30}$ Azyumardi Azra, Jaringan Ulama Timur Tengah dan Kepulauan Nusantara ..,h.270309. 
1203/1789, ketika dia menyelesaikan karyanya yang paling masyhur yaitu Sayr alSalikin. Ada juga yang mengatakan tahun 1244/1828.

Di Haramayn, al-Palimbani terlibat komunitas Jawa dan menjadi kawan seperguruan Muhammad Arsyad al-Banjari, 'Abd al-Wahhab Bugisi, 'Abd alRahman al-Batawi dan Dawud al-Fatani. Gurunya yang terkenal adalah Muhammad bin 'Abd al-Karim al-Sammani, Muhammad bin Sulayman al-Kurdi, dan 'Abd al-Mun'im al-Damanhuri, Ibrahim al-Ra'is, Muhammad Murad, Muhammad al-Jawhari, 'Atha' Allah al-Mashri, dan 'Abu al-Fawz 'Ibrahim bin Muhammadi al-Ra'is al-Zamzami al-Makki (1110-94/1698-1780) serta Muhammad bin Ahmad al-Jawhari al-Mishri (putra seorang muhadis Mesir terkemuka). ${ }^{31}$

\section{Muhammad bin Umar Nawawi al-Jawi al-Bantani (1813-1897)}

Muhammad bin Umar Nawawi al-Jawi al-Bantani yang dikenal dengan nama Nawawi Banten lahir di Tanara, Banten. Ia pergi ke Mekkah pada tahun 1828 ketika berumur 15 tahun dengan tujuan thalab al'ilm, sebagai murid dari komunitas Jawi dan ulama Makkah, tetapi juga mengabdikan hidupnya dalam karier intelektual terkemuka di Timur Tengah sebagai Sayyid Ulama al-Hijaz. Ia juga menjadi salah satu ulama paling penting yang berperan dalam proses transmisi Islam ke Hindia Belanda. Karya-karyanya kebanyakan berupa komentar atas kitabkitab terkenal yang menjadi salah satu materi utama yang dipelajari dalam pembelajaran Islam di pesantren, yang membuatnya menjadi salah satu sumber intelektual bagi perkembangan diskursus Islam di Hindia Belanda pada abad ke-19. Guru ulama Jawi di Timur Tengah yang pertama kali mengajarkan Nawawi yaitu Syaikh Abdul Ghani dari Bima, pulau Sumbawa, Syaikh Ahmad Khatib dari Sambas, Kalimantan, dan Syaikh Ahmad bin Zaid seorang syaikh-haji untuk kontingen haji dari Solo, jawa Tengah. Ia juga belajar Islam dari ulama lain seperti Yusuf Sumbulaweni, Nahrawi, dan Abdul Hamid al-Daghestani. ${ }^{32}$

\section{Mahfudz Termas (1868-1919)}

Mahfudz Termas lahir di Tremas, sebuah kota kecil di Pacitan, Jawa Timur. Ia tumbuh di lingkungan pesantren dan belajar Islam dari ayahnya, Kiai Abdullah, seorang ulama dari pesantren terkenal di Tremas, dan Kiai Saleh Darat seorang ulama Jawa terkenal di Semarang, Jawa Tengah. Pada tahun 1880-an dia pergi ke Mekkah bergabung dengan para pelajar yang belajar kepada para ulama Jawi terkemuka seperti Nawawi Banten. Diantara gurunya yang lain di Makkah yaitu Muhammad al-Munsyawi (w 1896), Syaikh Umar bin Barakah al-Syami (w 1895), Syaikh Mustafa bin Sulaiman al-Afifi (w 1890), Sayyid Husain bin Muhammad bin

${ }^{31}$ Azyumardi Azra, Jaringan Ulama Timur Tengah dan Kepulauan Nusantara ..,h.318323.

\footnotetext{
${ }^{32}$ Jajat Burhanudin, Ulama dan Kekuasaan..., h. 113-114.
} 
Husain al-Habsyi (w 1991), mufti Makkah Syafi'I Muhammad Babasil al-Hadrami (w 1911), dan Syeikh Abu Bakar bin Sayyid Muhammad Syatta (w 1892). ${ }^{33}$

Pengalaman belajar dari ulama-ulama di Makkah tersebut memberi Mahfudz beragam ilmu pengetahuan Islam. Ia lebih dikenal sebagai ahli hadis, 20 kitabnya memperlihatkan minatnya yang luas mulai dari persoalan-persoalan ritual (fiqih) sampai teologi. Dia menghabiskan hidupnya di Makkah mengikuti jejak Nawawi untuk memberi pengajaran terutama kepada ulama Jawi dalam halaqah di Masjidil Haram dan ia juga menjadi guru spiritual para ulama pesantren. Dari tangan Nawawi dan Mahfudz, lahirlah sejumlah ulama terkemuka seperti Khalid Bangkalan (w 1923) dari Madura dan Hasyim Asy'ari (1871-1947) dari Jombang, Jawa Timur.

\section{KESIMPULAN}

Haramayn merupakan pusat intelektual dunia Muslim, dimana ulama, sufi, filosof, penyair, pengusaha dan sejarawan Muslim bertemu dan saling menukar informasi. Hubungan antara kaum Muslim di Indonesia dan Timur Tengah telah terjalin sejak awal masuknya Islam yang dibawa oleh para pedagang muslim dari Arab. Sejak abad ke-17 hubungan antara Islam di Nusantara dengan Timur Tengah umumnya bersifat keagamaan dan keilmuan, meski juga terdapat hubungan politik antar beberapa kerajaan Muslim Nusantara, misalnya dengan Dinasti Utsmani. Upaya Dinasti Utsmani mengamankan jalur perjalanan haji, membuat semakin banyak penuntut ilmu dan jemaah haji dari Indonesia yang berkesempatan mendatangi pusat keilmuan Islam di Timur Tengah.

Peran penting Makkah, Timur Tengah tidak hanya sebagai pusat pengajaran Islam, tetapi juga sebagai pusat pembentukan para ulama. Hubungan intelektual dilakukan oleh para ulama terkait dengan paham keagamaan. Kecendrungan intelektual-keagamaan paling mencolok adalah harmonisasi antara syariat dan tasawuf. Diantara tokoh intelektual dari Indonesia yang pernah belajar ke Timur Tengah yaitu: Nur al-Din al-Raniri, Abd al-Ra'uf al-Sinkili dan Muhammad Yusuf al-Maqassari, 'Abd al-Shamad al-Palimbani, Muhammad bin Umar Nawawi alJawi al-Bantani, dan Mahfudz Termas.

Para ulama Timur Tengah dengan para pelajar dari Indonesia memiliki hubungan intelektual dalam bentuk murid dan guru di lingkungan komunitas Jawi, yang telah memberikan andil yang sangat besar bagi pengakuan luas dari masyarakat bahwa mayoritas ulama Nusantara yang belajar di Timur Tengah mempunyai wibawa atau reputasi keulamaan yang baik. Hal ini dikarenakan para pelajar atau ulama yang belajar di Timur Tengah memiliki pengalaman dan menguasai Ilmu pengetahuan, ilmu agama dan tradisi keulamaan berbasis AlQur'an dan Hadis serta kitab klasik dengan baik. Mereka ahli dalam bidang tersebut.

${ }^{33}$ Jajat Burhanudin, Ulama dan Kekuasaan..., h. 115. 


\section{DAFTAR PUSTAKA}

AS. Hornby, EV. Gatenby, H. Wakefield, The Advenced Learner's Dictionary of Current English, Oxford: Secon Edition, 1962.

Azyumardi Azra, Isei-Isei Intelektual Muslim dan Pendidikan Islam, Jakarta: Logos Wacana Ilmu, 1998.

Azyumardi Azra, Jaringan Ulama Timur Tengah dan Kepulauan Nusantara Abad XVII dan XVIII: Akar Pembaruan Islam Indonesia, Jakarta: Kencana Prenadamedia Group, 2013.

George A. Theodorson and Achilles Theodorson, A Modern Dictionary of Sociology, (New York: Barner and Noble Books, 1979), hal.210 dalam Azyumardi Azra, Isei-Isei Intelektual Muslim dan Pendidikan Islam, Jakarta: Logos Wacana Ilmu, 1998.

Hasan Asari, Menguak Sejarah Mencari Ibrah: Risalah Sejarah Sosial-Intelektual Muslim Klasik, Medan: Perdana Publishing, 2017.

Hasan Asari, Sejarah Pendidikan Islam: Membangun Relevansi Masa Lalu dengan Masa Kini dan Masa Depan, Medan: Perdana Publishing, 2019.

https://id.wikipedia.org/wiki/Walisongo.

Haidar Putra Daulay, Sejarah Pertumbuhan dan Pembaharuan Pendidikan Islam di Indonesia, Kencana, Prenada Media Group, Jakarta, 2007.

Jajat Burhanuddin, Ulama dan Kekuasaan: Pergumulan Elit Muslim dalam Sejarah Indonesia, Jakarta: Mizan Publika, 2012.

John M. Echol dan Hassan Shadily, Kamus Inggris Indonesia, Jakarta: Gramedia, 1981

Kamus Besar Bahasa Indonesia, Edisi Kelima, Badan Pengembangan dan Pembinaan Bahasa Kementerian Pendidikan dan Kebudayaan, 2018.

Samsul Nizar, Sejarah dan Pergolakan Pemikiran Pendidikan Islam: Potret Timur Tengah Era Awal dan Indonesia, Ciputat: Ciputat Press Group, 2005.

Sulasman dan Suparman, Jejak Islam di Asia \& Eropa: Dari Masa Klasik Hingga Masa Modern, Bandung: Pustaka Setia, 2013. 